\title{
A mídia nos crimes de colarinho branco e o judiciário
}

\author{
The media in white-collar crime and the judiciary
}

Michele Saito $^{1}$

\begin{abstract}
Resumo
É notável que, a atuação da mídia na sociedade brasileira tem o poder de influenciar a opinião pública, uma vez que a informa e constrói a realidade. Embora seu papel seja de suma relevância para a democracia, esta pode ser colocada em risco quando ocorrer o descomprometimento com a qualidade das informações veiculadas, com 0 intuito de alcançar os altos níveis de ibope e liderar a concorrência. Este proceder recai não apenas nos interesses do cidadão afetado em sua honra, intimidade, imagem, como também, dificulta a realização de um julgamento justo, isto é, livre de pressões e preconceitos. Em paralelo, este presente artigo procura exatamente mostrar que o especial enfoque da ação midiática, caso seja desempenhada com ética, constitui um arsenal poderoso para apurar os crimes que envolvem criminosos do colarinho branco de forma a viabilizar a eficiência do Direito Penal, além de trazer benefícios para a sociedade. Por fim, dá-se ênfase ao Judiciário em face da mídia e como se verá, serão apresentadas propostas de regulação que limitem a atividade da imprensa.
\end{abstract}

Palavras Chave: Mídia; Crime de Colarinho Branco; Judiciário.

\begin{abstract}
It is noteworthy that the role of media in Brazilian society has the power to influence public opinion, since the information and constructs a reality. Although their role is of utmost importance to democracy, this can be put at risk occurs when the disengagement with the quality of reports in order to achieve high levels of lead and sweeps competition. This lies not only in the interests of affected citizens in their honor, privacy, image, but also hinders the achievement of a fair trial, that is, free from pressures and prejudices. In parallel, the present article tries to show that exactly the particular focus of media activity, if performed with Ethics, is a powerful armory to investigate crimes involving white-collar criminals in order to facilitate the efficiency of criminal law, and bring benefits to society. Finally, there is emphasis on the judiciary in the face of media and will be, will be submitted for regulation to limit the activity of the press.
\end{abstract}

Keywords: M edia; white-collar crime; Judiciary.

${ }^{1}$ Graduada em Direito pelo Centro Universitário Euripedes de Marília (2006). Pós-graduada em Direito e Processo Penal pela Universidade Estadual de Londrina (2010). Pós-graduada em Direito e Processo do Trabalho pela Faculdadede de Direito Professor Damásio de Jesus (2011). M estranda em Direito Regulatório e Responsabilidade Social Empresarial pela Universidade Ibirapuera - UNIB. Advogada 


\section{Introdução}

A mídia integra a atual realidade social de modo que, é praticamente impossível conjeturar uma coletividade desenvolvida ou rumo ao desenvolvimento sem a presença maciça dos meios de comunicação.

Hodiernamente, em virtude do fenômeno chamado globalização, a atuação da mídia pode vir a constituir tanto um mecanismo poderoso na formação da opinião pública como uma locomotiva no desenvolvimento humano.

No entanto, a relevância da problemática a ser exposta é bastante explícita quando se verifica que a imprensa sem critério e a cautela devida divulga fatos inverídicos e até informações errôneas em detrimento de satisfazer a elevação dos índices de audiência.

Por conseguinte, este proceder não incide somente em face dos direitos da personalidade dos cidadãos, compromete, principalmente, na correção da distribuição da justiça quando os casos ainda estão submetidos à investigação ou ao crivo Judiciário.

Outro ponto a ser analisado nesse presente artigo, é a novidade que ocorreu no caso brasileiro no fim dos anos 80, qual seja, a atenção da mídia para escrachar publicamente os novos personagens do mundo do crime (banqueiros, políticos, empresários etc.), reiterando uma antiga praxe contra os pobres que antes eram criticados como violadores dos direitos humanos, mas que agora, paradoxalmente, soa como a democratização da imprensa e do direito penal.

Em contrapartida, mencionou-se que, a mídia, quando realiza suas próprias investigações ela contribui para apontar os crimes praticados por pessoas fora do quadro de eleição do sistema, ou seja, os de colarinho branco, tal atuação, portanto, revela-se imprescindível na busca de dar efetividade ao sistema penal, além de ser benéfica para a realidade brasileira.

Outrossim, procurou-se, em especial, enfatizar o Judiciário. 0 ponto nevrálgico da questão nesta abordagem diz respeito à pressão que os juízes sofrem por parte da opinião pública ou pela influência da ação midiática.

Por fim, como se verá, serão apresentadas propostas de regulação com a finalidade de limitar a atuação da imprensa.

O procedimento metodológico utilizado neste artigo é o dedutivo. Isso significa dizer que a construção do saber jurídico aqui pretendida dá-se pela extração discursiva do 
conhecimento a partir de premissas gerais aplicáveis a hipóteses concretas, ou seja, parte-se de argumentos gerais para argumentos específicos.

Oportuno salientar que, com o levantamento de documentação existente sobre 0 tema, desencadeou-se uma série de procedimentos para a localização e busca metódica dos documentos que interessam ao tema discutido, tais como pesquisas realizadas em livros, internet, revistas etc.

Devendo-se mencionar também, que não se pretende aqui exaurir de forma alguma a temática. Muito pelo contrário, objetiva-se com o amparo dos pontos de vista de renomados estudiosos, fomentar ainda mais o debate acerca do intrigante tema a ser abordado.

\section{A influência da mídia na sociedade}

Vivemos uma época na qual é evidente o grande impacto causado pelo avanço tecnológico, econômico, político, social e cultural.

A sociedade contemporânea tornou-se mais complexa e grande parte da comunicação humana passou a ser intermediada pelos meios de comunicação, os quais funcionam como poderosos instrumentos na construção e compreensão da realidade.

É notório que, diariamente recebemos inúmeras informações por meio da televisão, de jornais, de revistas, de rádios, da internet, de vídeos e de tantos outros meios que estão em todo lugar e em qualquer tempo, tornando-se a mídia onipresente nos dias atuais.

A mídia por ter a capacidade de atingir grandes contingentes de indivíduos é considerada um patrimônio social essencial para que o direito à comunicação possa ser exercido (FANTAZZNI, 2006).

Nesse contexto, ressalta-se que, o direito à comunicação sempre foi à base de todas as liberdades conquistadas pela humanidade no decorrer dos tempos, contribuindo de forma significante para o progresso das pessoas, bem como, para o conjunto das sociedades que almejam a construção de um Estado Democrático.

Illuminati (2001, p. 53), afirma, e de certa forma, com razão que: "a sociedade contemporânea faz da informação um elemento estruturante da sua própria organização". 
Atualmente, as informações difundidas pela mídia como espaço de força e domínio tem o poder de atuar na construção da opinião popular e no desenvolvimento humano.

A atuação midiática tem o condão de modificar o conteúdo e o significado da própria realidade, visto que, influencia profundamente na formação dos valores sociais.

Logo, verifica-se que o impacto da mídia na vida cotidiana é incomensurável. Afinal, ela está compondo a esfera ou o ambiente da vida contemporânea.

\section{Liberdade de imprensa x construção da realidade e julgamento pela mídia}

A precípua finalidade da imprensa, além de informar e propalar fatos, é a de difundir conhecimentos, disseminar a crença e a cultura, aclarar as consciências, canalizar as aspirações populares. Enfim, estimular e orientar a opinião pública para que possa trilhar o caminho do bem e da verdade.

Para tanto, é preciso, fundamentalmente, liberdade de expressão e manifestação de pensamento, tendo em vista que, a imprensa tem o dever de informar e a sociedade 0 direito de ser informado.

Segundo Gregório Badeni (apud VIEIRA, 2003, p. 32) salienta que:

Esse direito de informação, englobando os direitos de investigar, difundir e receber informações por intermédio dos meios de comunicação de massa pode ser entendido como o direito à liberdade de imprensa. Ela é concebida, modernamente, como o exercício da liberdade de expressão de maneira pública e mediante qualquer meio técnico de comunicação social.

Ademais, torna-se imperioso reviver os ensinamentos de Marx (2000, p. 65), em artigo intitulado "Debate sobre a liberdade de imprensa e comunicação", in verbis:

A imprensa livre é o olhar onipotente do povo, a confiança personalizada do povo nele mesmo, o vínculo articulado que une o indivíduo ao Estado e ao mundo, a cultura incorporada que transforma lutas materiais em lutas intelectuais, e idealiza suas formas brutas. [...] A imprensa livre é o espelho intelectual no qual o povo se vê, e a visão de si mesmo é a primeira confissão da sabedoria.

A imprensa livre é a interprete da opinião pública e corrobora na conformação das atitudes humanas e em suas formas de conduta. 
Deve-se, portanto, a imprensa transmitir ao público os fatos em face das ocorrências existentes no curso dos acontecimentos e as idéias objetivamente sem desfigurar-lhes a verdade ou esvaziar-Ihes o sentido original.

Andrade (1997, p. 28) aponta que: "o instituto da imprensa livre" é "garantia institucional da imprensa como um dos portadores e difusores da opinião pública no interesse de uma democracia livre".

Assim, uma comunidade que garanta o acesso à informação, aos meios de comunicação e que assevere condições para que os seres humanos possam ter liberdade de expressão e de comunicação poderá ser considerada verdadeiramente democrática.

Não obstante, a atuação da imprensa numa sociedade desempenhe um papel importante para a democracia, esta pode ser perigosamente ameaçada quando fatos são manipulados ou criados pela imprensa em decorrência de disputa mercadológica ou de poder. Este proceder, muitas vezes pode levar ao afastamento da verdade como elemento fundante da informação.

Vieira (2003, pp. 44-45) expõe que:

Com as grandes empresas de comunicação a informação se tornou uma mercadoria, sem qualquer valor relacionado à função social e à verdade. [...] A concorrência entre as empresas controladoras dos meios informativos faz com que nestes se misturem entre produtos de marketing, serviços para o leitor, notícias que tenham a potencialidade de satisfazer o público da sociedade de consumo. Para tanto, publicam fatos escabrosos, escândalos, denúncias, que agucem a curiosidade do leitor ou telespectador e que sejam vendáveis.

Diante disso, o problema enaltece quando nesta busca desenfreada pela atenção das massas surgem grandes distorções na veiculação de informações sem o mínimo de comprometimento com a função social.

Drapkin (1983, p. 19) salienta que:

[...] sonegar notícias ou retardar a publicação de outras até quando fosse oportuno; misturar notícias com opiniões condenatórias ou de aprovação; ampliar fatos insignificantes e reduzir o destaque de outros, de real importância; utilizar frases sentimentais, com vista a despertar a simpatia ou a antipatia [...] são práticas conhecidas, e era exatamente o que fazia a imprensa hitlerista. 
Contudo, se num regime que se justifica sob a força é facilmente concebível e explicável um direcionamento monolítico e único da publicação dos fatos, numa democracia torna-se espantoso, perceber que os diferentes órgãos divulgadores das informações atuam dentro de uma mesma lógica, isto é, com o objetivo de elevar os índices de audiência e liderar a concorrência (TORON, 2001, p. 262).

Com propriedade, a jornalista Cleinnman (2001, p. 23), sob o título “There's no business like new business", advertiu para o fato de que: "A existência de uma grande quantidade de meios e veículos informativos não gera uma pluralidade de temas, abordagens, personagens, pontos de vista, desmentindo as potencialidades tão louvadas da era da comunicação."

E ainda, continua explicando que esse fenômeno ocorre porque:

Contrariamente a qualquer indústria em que a concorrência obriga cada um a propor produtos diferentes, na indústria midiática ela leva os jornalistas a fazer prova de mimetismo, a dedicar to do o seu talento a repetir a mesma história, a tratar o mesmo assunto que mobiliza, no mesmo momento, todos os veículos.

Oportuno é que, a atividade midiática tem manipulado a informação, adequando-a as suas conveniências, agindo como se não sofressem impedimentos. Segundo manifestação expressiva de Bastos (1999, p. 113):

Nada mais falso do que essa visão mecanicista, simplista e deformadora. Ao contrário, o que se verifica hoje, tanto nos países centrais como nos periféricos, é que a mídia não é apenas uma cronista da realidade; ela se torna, cada dia mais, a protagonista da realidade, influindo, modificando e construindo fatos, interagindo com atores da vida real a ponto de constituir uma outra realidade - diferente da vida real.

Na síntese de Schecaira (1995, p. 137), os meios de comunicação se adaptam às noções de valores que supõem dominantes, "mas também os modificam e deformam o comportamento social".

Entretanto, pode-se dizer que, a atuação dos meios de comunicação transforma a realidade no sentido de edificar verdade que se inculcam nos cidadãos, máxime naquelas mais simples, e em regra, com menor capacidade de crítica (TORON, 2001, p. 265).

A mídia exerce uma enorme influência na sociedade cujo discernimento pressupõe uma análise crítica do receptor para selecionar e internalizar as informações que considera 
úteis para si, haja vista a parcialidade na divulgação das notícias que muitas vezes já chegam ao receptor de forma compactada, distorcida e manipuladora dificultando o desenvolvimento real do senso crítico.

Bucci (1997, p. 12) dispõe que:

A televisão se apresenta com os mecanismos necessários para integrar expectativas diversas e dispersas, os desejos e as insatisfações difusas, consegue incorporar novidades que se apresentem originalmente fora do espaço que ela ocupa e, em sua dinâmica, vai dando os contornos do grande conjunto, com um tratamento universalizante das tensões.

Ainda, de acordo com Baratta (1991, p. 56):

Como nas sociedades contemporâneas a comunicação das experiências, da ocorrência de fatos e até de sentimentos cada vez mais acontece no âmbito da mídia, sobretudo pela televisão, a grande maioria das pessoas crêem no que vêem, ouvem e lêem nos rádios, televisões, jornais e revistas.

Ululante é que, a população não deve se colocar como mera receptora passiva daquilo que é veiculado pela imprensa. Para tanto, é necessário que o receptor sujeite-se a um constante exercício logístico de equilíbrio e bom senso para identificar o que é excesso, o que é imaginário, daquilo que é fato verídico.

\section{Os novos personagens do crime}

No que diz respeito à criminalidade, um dos maiores desafios contemporâneos concentra-se, sem dúvida, no estudo do crime contra a ordem econômica, com especial ênfase no crime de colarinho branco.

Sendo assim, constata-se que, a tutela penal da atividade econômica constitui matéria complexa e de difícil compreensão dada à profusão de elementos normativos e de normas penais em branco, além da noção de bem-jurídico pouco delineada (PRADO, 2007).

Desta forma, antes de adentrar na temática a que este artigo se propõe, salutar é fazer breves considerações acerca do crime do colarinho branco.

0 termo White-collor crime surgiu na década de 30 , por meio dos estudos de Sutherland, com o objetivo de desmoronar a idéia construída em torno de que a criminalidade deriva em grande parte das camadas menos favorecidas da sociedade. Para 
tanto, Sutherland centralizou sua atenção nas características do agente criminoso e concluiu que o crime do colarinho branco é um delito cometido por uma pessoa de respeitabilidade e de elevado status sócio-econômico, no desempenho de suas atividades empresariais, acontecendo na maioria das vezes, uma violação de confiança (FRANCO, 2009).

É sabido que diversos autores rechaçaram a definição dada por Sutherland, gerando uma controvérsia em torno do conceito que até hoje se encontra em aberto. Contudo, para que a problemática da desigualdade na administração da justiça penal tenha um alicerce, essa conceituação tem sido considerada (FRANCO, 2009).

Nota-se que, o sistema penal, vem ao longo dos anos sofrendo alguns reflexos em decorrência de várias transformações que está acontecendo atualmente no mundo, restaurando, de um modo geral, a insegurança, bem como, fazendo emergir uma criminalidade diferente da clássica: a criminalidade econômica.

A prova mais evidente dessa afirmação é a análise do criminoso que até recentemente era o pobre, o desprivilegiado, o desintegrado, o marginal da sociedade e compará-lo com o criminoso do colarinho branco.

Constata-se, portanto, que a repressão penal não mais se dirige, quase exclusivamente, contra as pessoas provenientes das classes sociais menos favorecidas, como ocorria até pouco tempo.

Destarte, com a aparição dos criminosos do colarinho branco, as injustiças e os abusos cometidos em face dos pobres que antes eram objeto de repugnância por parte de entidades civis e da esquerda, passaram a ser de certa forma, incentivado e aplaudido atualmente como se fosse à democratização do Direito Penal e da imprensa (TORON, 2001, p. 263).

Incisivo a respeito foi um acórdão do TJSP, relatado pela Desa. Luiza Galvão (TJSP HC no 311.499-3 - julgamento 04.05.2000) ao "lembrar" que também "poderosos" têm direito à justiça no sentido de que o Judiciário agirá sempre com serenidade, sem se levar por ondas de opinião pública ou alarde nos meios de comunicação, "sem distinções e sem pré-julgamento. Nesse contexto, tem-se a nítida impressão de que a imprensa cultiva uma ideologia da "hora e a vez da burguesia na polícia".

Diante do exposto, no referido acórdão, Toron (2001, p. 264) salienta que: 
Com esta forma de pensar, esquece-se que, numa sociedade edificada sobre a base da dignidade humana, estampada na Constituição como valor reitor (art. $1^{\circ}$, III) e que presume a inocência do cidadão (art. $5^{\circ}, \mathrm{LVII}$ ), não se pode conviver com a execração pública, degradação e linchamento moral dos indivíduos, ainda que abastados, como forma de exercício de poder, tal qual se fazia sob o absolutismo, Por outras palavras, o que ontem se combateu como opressão dirigida aos segmentos desfavorecidos, porque afrontoso aos Direitos Humanos, não pode, perversamente, vir validado e aplaudido hoje, como se fosse a "democratização do direito penal" ou a da cobertura da imprensa, que agora também atinge os ricos.

Em virtude da ampliação do espectro de incidência do Direito Penal com a edição de novas leis e da atuação das agências de controle (polícia, procuradoria, ministérios públicos etc.), como também, a atenção da mídia em particular, acarretaram na prática de espezinhar e escrachar os políticos, banqueiros, empresários etc., estendendo-se, portanto, ao segmento mais bem aquinhoado da sociedade (TORON, 2001, p. 260).

Pondo em foco a realidade social, a atuação midiática, ultimamente, está a despertar uma nova consciência, direcionando as suas atenções, sobretudo, para os delitos praticados fora dos olhos do povo, ou seja, no recanto de gabinetes ou em lugares aparentemente insuspeitos (FRANCO, 2009).

Em outras palavras, a mídia tem tido uma papel fundamental e de grande relevância na apuração dos delitos que envolvem criminosos do colarinho branco.

Por razões óbvias, a maior preocupação da sociedade é com a violência que ocorre nas ruas, nos locais públicos, por ser ela visível e porque vítima e criminoso estão mais próximos, causando, assim, um impacto imediato (LEÃO, 1998).

Para reafirmar essa compreensão acima, Franco (2009) faz a seguinte observação:

A visibilidade da infração dos menos favorecidos é muito maior. A polícia atua em lugares de livre acesso (ruas, praças, supermercados, favelas, etc.) e esses locais são em massa freqüentados pelas classes sociais menos favorecidas. É lógico que a aquisição da notícia da infração e, por conseqüência, do início do procedimento investigatório sobrevirá das condutas praticadas pelos miseráveis. Ao contrário, como membros de classe média e alta passam a maior parte do tempo em lugares fechados, imunizados contra a atuação da polícia (casas, apartamentos, escritórios, clubes de elite, restaurantes e boates de luxo, automóveis privados), há muito mais probabilidade de serem os delitos mais miseráveis 'vistos' e registrados pela polícia, do que aqueles perpetuados pelas pessoas de posição mais elevada.

Marty (1990) conceitua a infração econômica como aquela que "ataca as estruturas relativas à produção, circulação, distribuição e consumo das riquezas de um determinado Estado." 
Vale salientar que, os crimes denominados de colarinho branco tornam-se cada vez mais assíduos. Por sua vez, a delinqüência nos negócios ameaça as estruturas do Estado, tendo em vista que, atinge a confiabilidade do sistema financeiro, econômico e social.

E ainda, a mídia não apenas aponta fatos e pessoas, como também efetua as suas próprias investigações. Não é raro observar a atuação midiática fornecendo à polícia ou ao Ministério Público os elementos concretos para as providências do aparelho do Estado (FRANCO, 2009).

A atuação midiática tem se mostrado mais hábil até para a localização de fugitivos criminosos da justiça. Nesse prisma, pode-se dizer, sem exagero, que a maioria dos fatos de grande repercussão no Brasil, nos últimos anos, envolvendo figuras expressivas da sociedade, foi, antes, levantada pelos órgãos da imprensa e as autoridades, por sua vez, chegaram posteriormente (FRANCO, 2009).

Assim, a demonstração da atividade da mídia tem sido um aparato apto ao combate à repressão da estrutura cada vez mais desafiante da delinqüência do colarinho branco, buscando dar efetividade ao sistema penal para capacitá-lo à mantença da ordem e da segurança pública.

Portanto, urge, assim, adequá-la à realidade da criminalidade brasileira, ante os extraordinários benefícios que podem dela advir, desde que praticada eticamente e aplicada com a lucidez necessária, de modo a viabilizar a eficiência do Direito Penal no embate contra o crime de colarinho branco, bem como, em prol da sociedade.

\section{0 judiciário}

Tendo em vista a realidade brasileira, é fundamental que nos dias atuais haja uma constante troca de informações peculiarmente entre magistrados e imprensa quando se tratar de assuntos envolvendo a justiça, a fim de que elas possam ser transmitidas de forma correta para a sociedade como um todo e para o público consumidor de notícias.

Entretanto, o que se verifica é o incremento de temores e dificuldades quando se pensa na pressão que o Judiciário sofre por parte da opinião popular ou naquela divulgada pela mídia (TORON, 2001, p. 267).

É certo que, a imprensa deve ter o direito e a liberdade para atuar, investigar, divulgar e informar ao público. 
Todavia, o problema surge quando a informação veiculada pelos órgãos da imprensa tende ao sensacionalismo ocasionando na violação não só do direito à honra, à intimidade e à imagem do cidadão, mas também, atentando contra a própria administração da justiça. Ou seja, podendo vir a prejudicar a realização de um julgamento justo, sobretudo quando os profissionais de imprensa formulam um pré-julgamento em casos ainda submetidos à investigação ou ao crivo Judiciário.

Conforme observa Nucci (1999, p. 226):

Ao arrepio das garantias mínimas de autodefesa e do direito ao silêncio, esses jornalistas enriquecem à custa da ignorância do povo, da ânsia de vingança, consciente ou não, que muitos carregam consigo diante da criminalidade crescente - fenômeno peculiar do ser humano. Assim, tão logo ficam sabendo da ocorrência de uma prisão - quando não acompanham a atividade policial, relatando e filmando todos os passos, tal como se fosse um seriado barato -, seguem para 0 distrito e passam a entrevistar o detido, com agressividade e prejulgamentos ímpares, buscando extrair dele a "confissão". Insistem, fazem perguntas capciosas, chegam a ofender 0 suspeito, contam com a complacência de muitos maus policiais, e, enfim por uma razão ou por outra, acabam conseguindo arrancar do indivíduo uma admissão de culpa, que é gravada e transmitida em rede nacional para todo país.

O papel da imprensa é informar e não julgar, conforme Vieira (2003, p. 157):

[...] a condição do indivíduo, de investigado, acusado ou réu não lhe retira o direito à dignidade. Seus direitos personalíssimos, que lhe são ínsitos, devem ser tutelados de forma eficaz. Embora previstos na Constituição, temos visto uma constante invasão dessa área reservada da pessoa envolvida em inquéritos ou processos criminais.

Nas palavras de Godoy (2001, p. 91):

[...] não se está a defender a total impossibilidade de 0 jornalismo, diante da notícia e cometimento de fatos delituosos, verificar sua procedência e divulgá-los. Seria o mesmo que negar o jornalismo chamado investigativo, que tantos serviços ao interesse público têm prestado. Trata-se, ao revés - mas o que também se faz haurido de exemplos recentes do que, ao contrário daqueles bons serviços, a precipitação na divulgação de fatos delituosos pode representar para a vida de pessoas indevidamente citadas -, de a um só tempo garantir essa atividade, mas desde que exercida com atenção aos limites que vão da presunção constitucional de inocência à preservação de um dever mínimo de verdade que, se não levado a extremos, da mesma forma não pode ser considerado inexistente relativamente aos acontecimentos delituosos. 
Deste modo, é notória a dificuldade em encontrar o justo ponto de equilíbrio entre 0 instituto da liberdade de imprensa de um lado e, de outro, os direitos fundamentais.

0 auge destes antagonismos pode ser condensado na contraposição entre justo processo e 0 julgamento pela mídia.

Nesse sentido, registrava o saudoso Filho (apud TORON, 2001, p. 268) no Memorial do "Caso Collor submetido ao STF":

Com a inegável e maciça penetração da imprensa no "mundo da justiça", os casos penais ficam submetidos a um "duplo debate". Este, trial by media, onde a igualdade de armas é inexistente, pois, além de vocalizarem-se fortemente as versões acusatórias, que na óptica da imprensa são sempre as mais interessantes de se divulgar para o grande público, criam-se situações para ensejar o "fato jornalístico", que estampa o clamor popular construído por pessoas, como já dito, adredamente arrebanhadas para protesto contra o "criminoso" e, com isso, possibilitar a prisão preventiva ou pressionar pela condenação.

Uma demonstração emblemática que ocorreu recentemente foi o caso Isabela Nardoni. Pai e madrasta foram presos e submetidos até agora a um linchamento moral, diante do comportamento da mídia. M esmo sendo apenas suspeitos, a imprensa mandou às favas a máxima da presunção da inocência e já proclamou e julgou o casal como os culpados pela morte da menina antes da devida apreciação do caso pelo Judiciário (ARAÚj0, 2008).

Verifica-se, portanto, que a vida das pessoas envolvidas foi bruscamente interrompida, suas intimidades devassadas.

0 acontecimento citado prossegue sem fechamento e vai continuar sendo explorado à exaustão pela mídia.

Outro caso considerado como um dos mais graves da relação polícia-mídiaacusados da história do país foi o da Escola Base. Este episódio veio a se transformar em símbolo de julgamento público açodado pela atuação da mídia, no qual se baseou em laudos preliminares e na acusação de mães que apontavam seis pessoas como envolvidas no abuso sexual de crianças numa escola de educação infantil, situada no bairro da Aclimação. A linha de investigação da Polícia se mostrou sem fundamento e o inquérito foi arquivado com a conclusão de que os acusados eram todos inocentes (HAIDAR, 2009).

No entanto, os acusados já tinham sido julgados sumariamente pelos jornais, revistas, programas de rádio, de televisão e condenados pela opinião pública. Com a inexatidão da mídia, a Escola de Educação Infantil Base foi pichada e saqueada. Outrossim, 
resultou no linchamento social dos acusados, depredação de suas moradias. Até hoje, há ações de indenização em andamento sobre este acontecimento (HAIDAR, 2009).

A Escola Base talvez tenha sido o caso em que houve maior autocrítica da imprensa. Júnior (2001, p. 188) assinala que é árdua a tarefa de perceber "se a revolta da sociedade é decorrência do choque que o crime causou no meio social, por si só, ou se a mencionada vingança do inconsciente popular é conseqüência da exploração e da distorção dos fatos pela mídia".

Destarte, a publicidade imediata, pré-processual, leviana, decorrente da imprensa sensacionalista tem sido determinante em muitos julgamentos.

Andrade (2007) afirma que:

0 problema surge quando a notícia veiculada pelos órgãos da mídia atropela ou mesmo atrapalha o trabalho desenvolvido no âmbito da seara jurídica, seja na esfera incipiente de investigação policial, na atuação do Ministério Público, nas decisões judiciais e até mesmo depois de cumprida a pena pelo cidadão condenado.

Conquanto se exija do magistrado uma maior imparcialidade, tendo em vista que possui uma preparação jurídica para julgar de acordo com a lei e seus princípios, a influência ou pressão da mídia quando produz juízos de valor têm levado a influir no convencimento do juiz, e conseqüentemente no resultado de suas decisões.

Nessa linha de pensamento comenta Sanguiné (2001, p. 268):

Quando os órgãos da Administração de Justiça estão investigando um fato delitivo, a circunstância de que os meios de comunicação social proporcionem informação sobre o mesmo é algo correto e necessário numa sociedade democrática. Porém uma questão é proporcionar informação e outra realizar julgamentos sobre ela. É preciso, portanto, partir de uma distinção entre informação sobre o fato e realização de valor com caráter prévio e durante o tempo em que se está celebrando o julgamento. Quando isso se produz, estamos ante um juízo prévio/paralelo que pode afetar a imparcialidade do Juiz ou Tribunal, que, por sua vez, se reflete sobre 0 direito do acusado à presunção de inocência e o direito ao devido processo.

De acordo com Toron (2001, p. 268):

Embora, alguns juízes possam ser intimidados pela ação da mídia, às vezes, até por características pessoais como, quem sabe, personalidade tímida, aversão à polêmica ou mesmo falta de estrutura emocional para suportar as inevitáveis 
críticas, e outro não, o certo é que isto não deveria acontecer. A seleção dos juízes deve também ser voltada ao recrutamento de indivíduos estruturados com adequação para enfrentar o ofício e a mídia limitada nesta que poderia ser considerada uma espécie de coação indireta no decorrer do processo.

Do exposto, pode-se concluir que a materialização dos excessos e injustiças praticadas pela atividade midiática deve ser combatida da forma mais feraz possível.

A publicidade dos atos processuais tem como finalidade assegurar um julgamento justo ao suspeito ou acusado, bem como, possibilitar um controle da atividade do Judiciário pela coletividade. Assim, não se pode permitir que ela esteja sendo empregada pelos meios de comunicação de massa de modo desvirtuado, contrariando necessariamente o que deveria garantir.

A imprensa não deve ser censurada, mas com toda liberdade há de ter restrições e responsabilidades quando da feitura de matérias jornalísticas.

\section{Propostas de regulação da atividade midiática}

A divulgação de forma abusiva e irresponsável dos fatos delituosos e de atos do processo põe em risco à ética concorrencial jornalística, os direitos da personalidade do cidadão, a árdua realização de um justo julgamento, bem como a iminente necessidade de repensar o balizamento legal do tema.

Illuminti (2001, p. 51), adverte que o problema é: "que a tutela da imparcialidade do juiz e o direito de informação sobre o processo não parecem valores fáceis de se balancear e, menos ainda, de conciliar".

Mais grave, menciona o professor da Universidade de Bologna (apud TORON, 2001, p. 269): "é que o remédio jurídico limitador da atividade da imprensa pode ser pior do que 0 dano que se quer evitar".

Para este autor, o ponto em questão é o problema cultural que, portanto, não será resolvido com leis restritivas.

Diversamente, da opinião do Professor bolonhês, Toron (2001, p. 270) aponta como solução, e de certa forma com razão:

A incidência de leis restritivas é uma necessidade não apenas para se preservar a honra e a imagem alheias, mas para se evitar a montagem do caso pela mídia de modo a se impedir que, posteriormente, uma absolvição ou arquivamento sejam 


\begin{abstract}
identificados pela desqualificadora expressão "tudo acabou em pizza". Programas como "Linha Direta" e similares, que normalmente reconstroem os fatos a partir de um prisma acusatório, deveriam ser proibidos antes do julgamento do acusado, sobretudo nos casos submetidos ao júri, pois tornam inarredável a futura condenação. De idêntica maneira, buscas policiais não podem ser alvo de acompanhamento, em tempo real, pela imprensa. Os policiais posam como agentes dos famigerados esquadrões da Swat e o espectador tem a impressão de que está diante de um cenário criminoso. Quando nada é encontrado na busca, afirma-se que os investigados são tão organizados que já sabiam da ação policial. Não há saída para o suspeito, a regra é a vox incriminadora, ou, no mínimo, comprometedora. A investigação deve ser coberta peal discrição.
\end{abstract}

Nesse contexto, uma medida adequada para regulamentar à atividade midiática seria a criminalização da conduta, com o objetivo de se impor limites à ação da imprensa em casos em que envolvam a intervenção da máquina judiciária.

Destarte, faz-se necessária a elaboração de um tipo penal, como constava do Anteprojeto da Parte Especial do Código Penal apresentado pelo grupo de trabalho constituído em 1987 pelo então M inistro da Justiça Paulo Brossard, criminalizando a coação indireta no curso do processo, com os aprimoramentos necessários, pode representar uma saída promissora (TORON, 2001, p. 270).

0 art. 352 do diploma apresentado tinha o seguinte teor:

Fazer em jornal, rádio, televisão, ou qualquer outro meio de comunicação, antes da intercorrência de decisão definitiva em processo judicial, comentários, com o fim de constranger ou exercer pressão relativamente a declaração de testemunhas ou a decisão judicial:

Pena: detenção de 3 (três) meses a um ano.

É verdade que o tipo penal pode necessitar de reparos, em peculiar quando alude à pressão como fim especial no agir do agente, que, entretanto, pode ser substituído por algum elemento normativo do tipo, de modo a precisar situações e confinar a incriminação (TORON, 2001, p. 270).

Entretanto, deve-se ter a devida cautela no momento da construção das normas penais, que devem ser feitas de forma racional e ter como suporte a nossa Constituição e os Tratados Internacionais sobre direitos humanos ratificados pelo Brasil (DÍEZ, 2005).

Uma outra proposta para caminhar no sentido de resolver este problema seria 0 Congresso Nacional formular uma nova lei para regulamentar as práticas jornalísticas na 
qual estabelecesse as diretrizes, restrições e principalmente que contivesse sanções em situações de descumprimento, sanções essas que coibiriam os excessos.

Em outras palavras, deveria ser criada uma nova Lei de Imprensa com o propósito de controlar a forma de atuação dos órgãos divulgadores das informações e prevenir abusos, especialmente quando versar acerca de reportagens jornalísticas irresponsavelmente divulgadas, nos casos em que se imponha a atuação dos órgãos da Justiça.

Oportuno mencionar que, a Lei de Imprensa do Brasil de 1967 é inconstitucional. 0 Supremo Tribunal Federal, por sete votos a quatro, julgou no dia 30 de abril de 2009, que a Lei 5.250/67 não foi recepcionada pela nova ordem democrática. Sob a justificativa de que a respectiva lei foi editada durante o período da ditadura militar a partir de uma ótica punitiva e cerceadora da liberdade de expressão (HAIDAR, 2009).

Nesse sentido, o jornal O Estado de S. Paulo (2009, p. 3) publicou:

\begin{abstract}
Como não está claro como os processos devem ser conduzidos a partir de agora, 0 vácuo jurídico está disseminando insegurança entre os órgãos de comunicação e no próprio Judiciário, onde tramitam milhares de ações contra jornais e jornalistas. [...] Diante das especificidades técnicas no campo do jornalismo, o "apagão jurídico" provocado pela revogação da Lei de Imprensa deixou jornais, revistas, rádios e televisões, além de promotores e juízes, sem regras claras que balizem principalmente as situações de conflito entre os direitos da informação e os da proteção à honra e à imagem.
\end{abstract}

Por conseguinte, somente uma regulação limitativa da atividade midiática é que poderá intimidar e tornar mais criteriosos os requisitos para a divulgação de informações relacionadas à vida e intimidade dos indivíduos, e inclusive, possibilitar um julgamento justo nos casos ainda submetidos à investigação ou ao crivo do Judiciário, sobretudo para impedir, a consumação de abusos e injustiças.

\title{
Conclusão
}

À guisa de conclusão, fica nítido que, a função da mídia na atual realidade brasileira é essencial na manutenção e na defesa da democracia.

Contudo, o gravame surge quando a mídia abusa de sua prerrogativa informativa, em virtude de poder ou de concorrência no mercado entre os atuantes nesse viés empresarial para atuar de maneira irresponsável, antiética ou invasiva, ameaçando assim, os 
direitos individuais do cidadão, e ainda, contaminando em especial o Judiciário na consecução da justiça.

Outrossim, procurou-se enfatizar que, o estudo do crime contra a ordem econômica, em peculiar, o delito designado de colarinho branco, constitui, sem dúvida, um dos temas mais complexos da contemporaneidade.

Deste modo, um dos objetivos deste trabalho foi mencionar que, a atividade midiática vem sendo um instrumento hábil no combate dos crimes de colarinho branco, contribuindo, portanto, de forma significante na busca de dar efetividade ao sistema penal. E ainda, se a imprensa atuar com ética ela poderá ser empregada em benefício da sociedade e para o fortalecimento da cidadania.

Por derradeiro, deu-se enfoque ao Judiciário perante a mídia e foram apresentadas propostas que forneceram restrições à ação da imprensa.

Nesse prisma, apresentou-se uma solução viável para a regulação limitativa da atividade midiática que foi a criação de um tipo penal criminalizando a coação indireta no curso do processo, como estabelecia o Anteprojeto da Parte Especial do Código Penal de 1987, todavia, devendo-se fazer os seus devidos aprimoramentos e reparos necessários.

Uma outra alternativa promissora mencionada foi o Congresso Nacional editar uma nova Lei de Imprensa nos termos da nossa Constituição, que imponha mecanismos para controlar os órgãos da imprensa e impedir a consumação de abusos, principalmente, quando as notícias difundidas pela mídia vir a prejudicar o trabalho desenvolvido no âmbito judicial.

Portanto, é necessária a incidência de leis restritivas na atuação midiática para que as informações não transcendam a apuração e divulgação dos fatos em situações que envolva a intervenção do Poder Judiciário, com a finalidade de se obstar a materialização de injustiças e excessos. Tendo em vista que não são apenas os direitos da personalidade que estão em jogo, mas sim a correção da própria justiça que se coloca em questão.

Por fim, nestas linhas exordiais, espera-se por meio deste trabalho ter colaborado com o desenvolvimento da matéria, semear um terreno pouco explorado pelas doutrinas, para assim suscitar a discussão, sempre com a finalidade construtiva de aperfeiçoar o tratamento do assunto. 


\section{Referências}

ANDRADE, Costa. Liberdade de imprensa e tutela penal da privacidade. A experiência portuguesa. Revista Brasileira de Ciências Criminais, São Paulo, out./dez. 1997, № 20, p. 28.

ANDRADE, Fábio M artins de. Mídia e Poder Judiciário: A Influência dos Órgãos da Mídia no Processo Penal Brasileiro. Rio de Janeiro: Lumen Juris, 2007. Disponível em বhttp://www.andrade.adv.br/pdf/M idia_Poder_Judiciario.pdf>. Acesso em: 29 jun. 2008.

ARAÚJO, Francisco Marcos de. A atuação da imprensa e da polícia no caso Isabela Nardoni: uma flagrante e polissêmica violação dos direitos humanos. Rio Grande, 31 mai. 2008. Disponível em: «ttp://www.ambito-juridico.com.br>. Acesso em: 23 fev. de 2009.

BARATTA, Alessandro. Introducción a uma socilogia de la droga, inserto nos Anais da Conferência internacional de Direito Penal de outubro de 1988, Rio de Janeiro: Centro de Estudos da Procurado ria-Geral da Defensoria Pública do Estado do Rio de Janeiro, 1991.

BASTOS, M árcio Thomaz. Mídia e júri. Tribunal do júri: estudo sobre a mais democrática instituição jurídica brasileira. Org. Rogério Lauria Tucci. São Paulo: Revista dos Tribunais, 1999. p. 113.

BATISTA, Nilo. Comunicação e crime. Punidos e mal pagos. Rio de Janeiro: Revan, 1990.

BUCCI, Eugênio. Brasil em tempo de TV. 3 ed. São Paulo: Boitempo, 1997. p. 12.

CLEINNM AN, Betch. A muralha dos procedimentos inquisitoriais. CPI: os novos comitês de salvação nacional. Org. Antonio Carlos Barandier. Rio de Janeiro, 2001. p. 23.

DÍEZ RIPOLLÉS, José Luis. A Racionalidade das Leis Penais. Tradução de Luiz Regis Prado. São Paulo: Revista dos Tribunais, 2005.

DRAPKIN, Israel. Imprensa e criminalidade. Tradução de Esther Kosovsky. São Paulo: José Buschatsky, 1983. p. 19.

FANTAZZINI, Orlando. 0 poder da mídia e os caminhos para a democratização dos meios de comunicação. São Paulo: Revista Pucviva, n. 25, out./mar. 2006. Disponível em বhttp://www.apropucsp.org.br/revista/r25_r08.htm>. Acesso em: 12 jan. 2009.

FRANCO, Alberto Silva. Crimes hediondos. 4. ed. São Paulo: Revista dos Tribunais, 2000.

FRANCO, Rodrigo Strini. Criminoso de Colarinho Branco. São Paulo, 19 jan. 2009. Disponível em http:// www.idecrim.com.br/artigo_ver.php?idTexto=47. Acesso em: 26 jul. 2009.

GARAPON, Antoine. 0 juiz e a democracia. 2 ed. Rio de Janeiro: Renovar, 1999. 
GODOY, Cláudio Luiz Bueno de. A Liberdade de Imprensa e os Direitos da Personalidade. São Paulo: Atlas, 2001. p. 91.

GOM ES, Luiz Flávio; CERVINI, Raúl. Crime organizado. 2 ed., São Paulo: Revista dos Tribunais, 1997.

GRINOVER, Ada Pelegrini. 0 processo em sua unidade. v. 2. Rio de Janeiro: Forense, 1984, n. 8, p. 50.

HABERM AS, Jürgem. Mudança estrutural da esfera pública. Tradução de Flávio Kothe. Rio de Janeiro: Forense, 1984.

HAIDAR, Rodrigo. STF decide que Lei de Imprensa é inconstitucional. Revista Consultor Jurídico, Brasília, 30 abr. 2009. Disponível em: «ttp://www.conjur.com.br/2009-abr-30/leiimprensa-inconstitucional-decide-supremo>. Acesso em: 15 jul. 2009.

ILLUM INATI, Giulio. Divieto di pubblicazione e formazione del convincimento giudiziale. In: Processo penale e informazione. Università degli studi di M acerata, Facoltà di Giurisprudenza, Istituto di Diritto e Procedura Penale, 2001, p. 51-58.

JÚNIOR, Roberto Delmanto. As modalidades de prisão provisória e seu prazo de duração. 2. ed., ampl. e atual. Rio de Janeiro: Renovar, 2001, p. 188.

LEÃO, M aria do Carmo. Os crimes do colarinho branco. Jus Navigandi, Teresina, ano 3, n. 27, dez. 1998. Disponível em http://jus2.uol.com.br/doutrina/texto.asp?id=1043. Acesso em: 23 abr. 2009.

M ARTY, M ireille Delmas. Droit Penal des Affaires. 3 ed. Partie générale. Tome 1. Paris: Puf, 1990.

M ARX, Karl. A liberdade de imprensa. Tradução Brasileira de Claúdia Schilling e José Fonseca. Porto Alegre: L\&PM, 2000, p. 65.

NUCCl, Guilherme de Souza. 0 valor da confissão como meio de prova no processo penal. 2 ed., São Paulo: Revista dos Tribunais, 1999, p. 226.

POR uma Nova Lei de Imprensa. O Estado de S. Paulo, São Paulo, 21 maio. 2009. Notas \& Informaç̧ões, p. A-3.

PRADO, Luiz Regis. Direito Penal Econômico. 2 ed., São Paulo: Revista dos Tribunais, 2007.

SANGUINÉ, Odone. A inconstitucionalidade do clamor público como fundamento de prisão preventiva. In: SHECARIA, Sérgio Salomão (Org.). Estudos Criminais em Homenagem a Evandro Lins e Silva (criminalista do século). São Paulo: M étodo, 2001, p. 257-295; Revista de Estudos Criminais. Porto Alegre: Notadez: PUCRS: ITEC, 2003, ano 3, n 10, p. 113-120. 
SHECAIRA, Sérgio Salomão. A criminalidade e os meios de comunicação de massa. Revista Brasileira de Ciências Criminais, São Paulo, abr./jun. 1995, v. 3, n.10, p. 137.

TORON, Alberto Zacharias. Notas sobre a mídia nos crimes de colarinho branco e 0 Judiciário: os novos padrões. Revista Brasileira de Ciências Criminais, São Paulo, out./dez. 2001 , v. 9 , n. 36, p. 257-271.

VIEIRA, Ana Lúcia M enezes. Processo Penal e Mídia. 1 ed., São Paulo: Revista dos Tribunais, 2003.

Artigo recebido em:

26 de maio de 2011

Artigo aprovado em:

05 de setembro de 2011 